\title{
Morphometrics of females, juveniles and a hermaphrodite of Longidorus distinctus Lamberti et al., 1983 (Nematoda: Longidoridae) from Slovakia
}

\author{
M. LIŠKOVÁ \\ Parasitological Institute, Slovak Academy of Sciences, Hlinkova 3, 04001 Košice, Slovak Republic, \\ E-mail: liskova@saske.sk
}

\begin{abstract}
Summary
A population of Longidorus distinctus Lamberti, Choleva \& Agostinelli, 1983 was recovered from soil samples collected from the rhizosphere of plum trees at Král'ovský Chlmec in south-eastern Slovakia. The area is characterized by sandy soil derived from dune sand. The population comprised females, juveniles of four developmental stages and a bisexual specimen. No males were found. It is the first record of this species from Slovakia. Two females were sequenced and the sequence was deposited in GenBank.
\end{abstract}

Key words: Longidorus distinctus; females; hermaphrodite; juvenile developmental stages; plum; sandy soil; Slovak Republic; Ribosomal DNA; 28S gene; PCR

\section{Introduction}

Observations of hermaphroditism in longidorid nematodes are rather scarce. This phenomenon was observed in Longidorus macrosoma Hooper, 1961 (Aboul-Eid \& Coomans, 1966), L. africanus Merny, 1966 (Cohn \& Mordechai, 1968), L. elongatus (deMan, 1876) Thorne \& Swanger 1936, including variability between hermaphrodite specimens (Raschké \& Boag, 1981), L. distinctus Lamberti, Choleva \& Agostinelli, 1983 (Krnjaic et al., 1999), L. helveticus Lamberti, Kunz, Grunder, Molinari, De Luca, Agostinelli \& Radici, 2001 (Barsi \& De Luca, 2005) and Xiphinema ingens Luc \& Dalmasso, 1964 (Lamberti et al., 1975).

During an investigation of occurrence and geographical distribution of plant parasitic nematodes in fruit orchards in south-eastern area of the Slovak Republic, a population of L. distinctus was found, and it is the first record of this species from Slovakia. The region is characterized by warm and dry climate with $10{ }^{\circ} \mathrm{C}$ annual average temperature, $500-600 \mathrm{~mm}$ annual average rainfall, an altitude about $100 \mathrm{~m}$ and by sandy soils derived from dune-sand.
This population of L. distinctus, which consisted of females, juveniles and a hermaphrodite specimen, occurred mixed with Xiphinema vuittenezi Luc, Lima Weischer \& Flegg, 1964, a longidorid species very frequent in specific drift sand landscape throughout Slovakia. Morphometrics of adults, juveniles and a hermaphrodite specimen are reported here to provide additional information on their natural variability.

\section{Material and Methods}

Morphological and morphometrical study

Soil samples were collected from the rhizosphere of plum (Prunus domestica L.) at the depth of $20-30 \mathrm{~cm}$, from the locality of Královský Chlmec, in the area of Východoslovenská rovina plain. Nematodes (14 females, 47 juveniles and 1 hermaphrodite) were extracted from $500 \mathrm{~g}$ of soil by a sieving and decanting method (Brown \& Boag, 1988), fixed in FAA and mounted on permanent slides in anhydrous glycerin. Nematode identification was performed by using a high-resolution light microscope with Nomarski differential interference contrast (DIC, Nomarski), photomicrographs were recorded with a digital camera linked to a computer, and measurements were made with the aid of an eyepiece scale. Due to deformation, measurements of some of the juveniles and females are not provided in Table 1.

\section{Molecular study}

For the molecular study two female specimens were separately added in $0.5 \mathrm{ml}$ Eppendorf microtubes containing 20 $\mu \mathrm{l}$ of $0.25 \mathrm{M} \mathrm{NaOH}$ under a binocular microscope and DNA was extracted according to a method described by Stanton et al. (1998). The DNA was used for polymerase chain reaction (PCR) directly after extraction. The D2 and D3 expansion regions of the large subunit (28S) of ribosomal DNA were amplified using the primer D2A (5'ACAAGTACCGTGAGGGAAAGTTG-3') and D3B (5'- 
TCGGAAGGAACCAGCTACTA-3' (De Ley et al., 1999). The relevant PCR and gel electrophoresis conditions were as described by Kumari et al. (2005). The region was sequenced after purification of PCR products from the gel slice with a Qiagen gel purification kit (Qiagen Inc., Valencia, CA). Purified DNA fragments were sequenced directly using forward and reverse primers.

\section{Results and Discussion}

Morphology and morphometrics

Longidorus distinctus Lamberti, Choleva \& Agostinelli, 1983

Female: body of medium size $(4.3-5.6 \mathrm{~mm})$, slender, ventrally curved in an open $\mathrm{C}$, tapering towards, evident glandular structure in hypodermal cords. Cuticle $2.1-2.4$ $\mu \mathrm{m}$ thick. Lip region laterally rounded, $10.0-12.0 \mu \mathrm{m}$ wide and $4.2-4.8 \mu \mathrm{m}$ high, offset from the rest of body by a slight depression. Amphidial pouches asymmetrically bilobed, reaching to half of anterior end to guide ring distance. Odontostyle, odontophore and guide ring typical of the genus. Oesophageal bulb measuring $98-112 \times 17-21$ $\mu \mathrm{m}$. Cardia small, slightly conoid. Vulva slit like; gonads amphidelphic with anterior branch $264-345 \mu \mathrm{m}$ long and posterior branch 236 - $354 \mu \mathrm{m}$ long. Ovaries reflexed; anterior reflexed part $120-180 \mu \mathrm{m}$ and posterior $108-$ $178 \mu \mathrm{m}$ long. Uteri consist of two distinct parts, i.e. with and without particular characters: $44-61 \mu \mathrm{m}$ and $80-108 \mu \mathrm{m}$

Table 1. Morphometrics of Longidorus distinctus from Slovakia. All measurements in $\mu \mathrm{m}$ except L (in form): mean \pm standard deviation (range).

\begin{tabular}{|c|c|c|c|c|c|c|}
\hline $\begin{array}{l}\text { Locality } \\
\text { Host }\end{array}$ & & & $\begin{array}{r}\text { Král'ovsky } \\
\text { Plu }\end{array}$ & $\begin{array}{l}\text { Chlmec } \\
\text { n }\end{array}$ & & \\
\hline Specimens & $\mathrm{J} 1$ & $\mathrm{~J} 2$ & $\mathrm{~J} 3$ & $\mathrm{~J} 4$ & Females & Intersex \\
\hline $\mathrm{n}$ & 1 & 3 & 6 & 6 & 12 & 1 \\
\hline $\mathrm{L}(\mathrm{mm})$ & 1.2 & $\begin{array}{c}1.5 \pm 0.1 \\
(1.4-1.6)\end{array}$ & $\begin{array}{c}2.2 \pm 0.1 \\
(2.1-2.4)\end{array}$ & $\begin{array}{c}3.6 \pm 0.3 \\
(3.1-3.9)\end{array}$ & $\begin{array}{c}5.1 \pm 0.4 \\
(4.3-5.6)\end{array}$ & 4.3 \\
\hline $\mathrm{a}$ & 58.6 & $\begin{array}{c}67.6 \pm 3.0 \\
(64.2-69.9)\end{array}$ & $\begin{array}{c}92.1 \pm 8.8 \\
(83.9-09.1)\end{array}$ & $\begin{array}{c}103.6 \pm 8.8 \\
(88.6-111.2)\end{array}$ & $\begin{array}{c}127.5 \pm 8.8 \\
(108.1-136.9)\end{array}$ & 108.0 \\
\hline $\mathrm{b}$ & 6.4 & $\begin{array}{l}7.3 \pm 0.3 \\
(7.1-7.6)\end{array}$ & $\begin{array}{l}8.6 \pm 1.7 \\
(6.1-9.5)\end{array}$ & $\begin{array}{l}10.8 \pm 1.5 \\
(8.9-12.5)\end{array}$ & $\begin{array}{c}13.7 \pm 1.6 \\
(11.3-15.9)\end{array}$ & 13.2 \\
\hline $\mathrm{c}$ & 30.6 & $\begin{array}{c}39.9 \pm 5.8 \\
(35.5-46.6)\end{array}$ & $\begin{array}{c}40.3 \pm 2.5 \\
(36.6-43.6)\end{array}$ & $\begin{array}{c}62.8 \pm 6.6 \\
(53.9-70.7)\end{array}$ & $\begin{array}{c}97.7 \pm 9.9 \\
(77.2-108.0)\end{array}$ & 70.0 \\
\hline$c^{\prime}$ & 3.2 & $\begin{array}{c}2.7 \pm 0.4 \\
(2.2-2.9)\end{array}$ & $\begin{array}{l}3.0 \pm 0.3 \\
(2.8-3.4)\end{array}$ & $\begin{array}{l}2.3 \pm 0.3 \\
(2.0-2.7)\end{array}$ & $\begin{array}{c}1.9 \pm 0.2 \\
(1.6-2.2)\end{array}$ & 1.9 \\
\hline V & - & - & - & - & $\begin{array}{c}47.8 \pm 0.7 \\
(47.2-49.5)\end{array}$ & 47.0 \\
\hline Odontostyle & 41.0 & $\begin{array}{c}48.7 \pm 0.6 \\
(48.0-49.0)\end{array}$ & $\begin{array}{c}61.0 \pm 4.7 \\
(52.0-64.0)\end{array}$ & $\begin{array}{c}73.5 \pm 3.1 \\
(70.0-78.0)\end{array}$ & $\begin{array}{c}82.3 \pm 2.3 \\
(79.8-84.0)\end{array}$ & 80.0 \\
\hline Odontophore & 30.0 & $\begin{array}{c}34.6 \pm 0.6 \\
(34.0-35.0)\end{array}$ & $\begin{array}{c}38.0 \pm 2.5 \\
(32.0-44.0)\end{array}$ & $\begin{array}{c}45.2 \pm 2.2 \\
(43.0-48.0)\end{array}$ & $\begin{array}{c}43.1 \pm 3.2 \\
(40.0-48.2)\end{array}$ & 48.0 \\
\hline Replacement odontostyle & 44.0 & $\begin{array}{c}54.0 \pm 2.0 \\
(52.0-56.0)\end{array}$ & $\begin{array}{c}67.2 \pm 5.2 \\
(58.0-72.0)\end{array}$ & $\begin{array}{c}79.7 \pm 2.1 \\
(76.0-82.0)\end{array}$ & - & - \\
\hline Oral aperture to guide ring & 18.4 & $\begin{array}{c}18.7 \pm 0.6 \\
(18.0-19.0)\end{array}$ & $\begin{array}{c}22.0 \pm 1.8 \\
(20.0-24.4)\end{array}$ & $\begin{array}{c}26.0 \pm 1.6 \\
(24.0-28.0)\end{array}$ & $\begin{array}{c}29.5 \pm 1.2 \\
(28.0-32.0)\end{array}$ & 28.0 \\
\hline Tail & 38.0 & $\begin{array}{c}40.0 \pm 4.0 \\
(36.0-44.0)\end{array}$ & $\begin{array}{c}55.8 \pm 2.7 \\
(52.8-60.0)\end{array}$ & $\begin{array}{c}54.9 \pm 2.4 \\
(52.0-58.0)\end{array}$ & $\begin{array}{c}52.0 \pm 2.5 \\
(48.0-56.0)\end{array}$ & 62.0 \\
\hline $\mathrm{J}$ (hyaline portion of tail) & 2.0 & $\begin{array}{l}2.7 \pm 1.1 \\
(2.0-4.0)\end{array}$ & $\begin{array}{c}5.8 \pm 1.8 \\
(4.0-8.0)\end{array}$ & $\begin{array}{c}8.2 \pm 2.7 \\
(4.0-10.0)\end{array}$ & $\begin{array}{c}13.5 \pm 2.3 \\
(10.2-16.4)\end{array}$ & 16.0 \\
\hline Body diam. at lip region & 6.4 & $\begin{array}{c}7.7 \pm 0.6 \\
(7.0-8.0)\end{array}$ & $\begin{array}{c}7.8 \pm 0.4 \\
(7.0-8.0)\end{array}$ & $\begin{array}{c}9.3 \pm 1.5 \\
(7.8-12.0)\end{array}$ & $\begin{array}{c}11.2 \pm 0.9 \\
(10.0-12.0)\end{array}$ & 11.6 \\
\hline Body diam. at guide ring & 11.9 & $\begin{array}{c}13.2 \pm 2.4 \\
(11.7-16.0)\end{array}$ & $\begin{array}{c}13.3 \pm 1.1 \\
(11.5-14.0)\end{array}$ & $\begin{array}{c}16.4 \pm 0.9 \\
(15.5-18.0)\end{array}$ & $\begin{array}{c}17.6 \pm 1.1 \\
(16.0-19.0)\end{array}$ & 17.4 \\
\hline $\begin{array}{l}\text { Body diam. } \\
\text { at base of oesophagus }\end{array}$ & 19.3 & $\begin{array}{c}19.7 \pm 0.6 \\
(19.0-20.0)\end{array}$ & $\begin{array}{c}24.3 \pm 0.9 \\
(23.6-26.0)\end{array}$ & $\begin{array}{c}30.4 \pm 1.7 \\
(28.0-32.0)\end{array}$ & $\begin{array}{c}34.0 \pm 1.8 \\
(32.0-36.0)\end{array}$ & 38.0 \\
\hline $\begin{array}{l}\text { Body diam. } \\
\text { at mid body or vulva }\end{array}$ & 19.6 & $\begin{array}{c}22.3 \pm 0.6 \\
(22.0-23.0)\end{array}$ & $\begin{array}{c}25.1 \pm 1.8 \\
(24.0-28.0)\end{array}$ & $\begin{array}{c}34.4 \pm 1.6 \\
(32.0-36.0)\end{array}$ & $\begin{array}{c}39.8 \pm 2.9 \\
(36.0-46.0)\end{array}$ & 48.0 \\
\hline Body diam. at anus & 12.0 & $\begin{array}{c}15.0 \pm 1.0 \\
(14.0-16.0)\end{array}$ & $\begin{array}{c}18.4 \pm 1.7 \\
(16.0-20.0)\end{array}$ & $\begin{array}{c}23.6 \pm 2.1 \\
(21.0-27.2)\end{array}$ & $\begin{array}{c}27.8 \pm 1.8 \\
(24.0-32.0)\end{array}$ & 35.0 \\
\hline $\begin{array}{l}\text { Body diam. } \\
\text { at beginning of } \mathrm{J}\end{array}$ & 4.0 & $\begin{array}{c}4.7 \pm 0.5 \\
(4.0-5.2)\end{array}$ & $\begin{array}{c}5.1 \pm 1.4 \\
(4.0-7.9)\end{array}$ & $\begin{array}{c}7.2 \pm 1.6 \\
(5.6-10.0)\end{array}$ & $\begin{array}{c}10.5 \pm 1.6 \\
(10.0-12.0)\end{array}$ & 10.0 \\
\hline Spicules & - & - & - & - & - & 44.0 \\
\hline Mucro & 3.0 & - & - & - & - & - \\
\hline
\end{tabular}




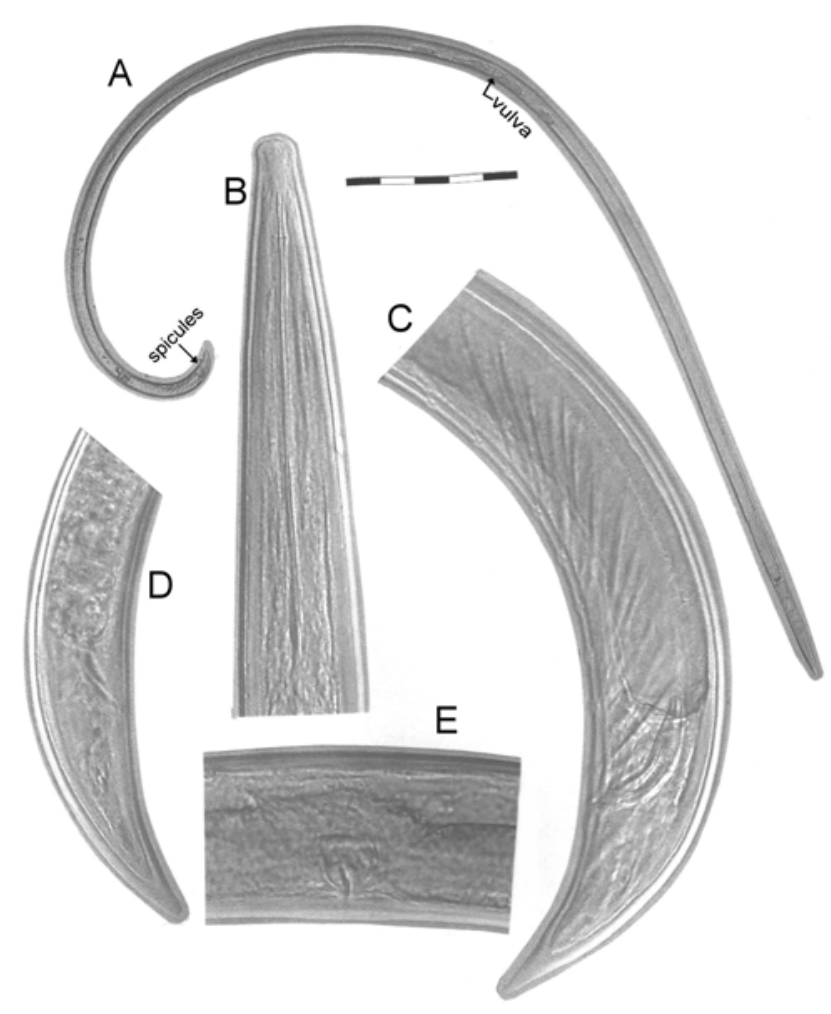

Fig. 1. Longidorus distinctus. A, B, C, E - Intersex specimen: A - Entire nematode; B - Anterior region; C - Posterior region; E - Vulva; D Posterior region of normal female. Scale bar: A: $500 \mu \mathrm{m}$; B-E: $50 \mu \mathrm{m}$

in anterior branch and $52-77 \mu \mathrm{m}$ and $81-120 \mu \mathrm{m}$ in posterior branch, respectively. Spermatheca rounded, 17 $30 \mu \mathrm{m}$ wide, sometimes covered by reflexed ovary. Tail dorsally convex, conoid, with gently rounded tip, bearing two pairs of caudal pores. Sometimes after beginning of hyaline portion more tapering cca $20 \mu \mathrm{m}$ from the end. Juveniles: separated into four developmental stages. In comparison to adults they are similar in body shape, which is slender, slightly arcuate; tail in all stages elongated, conoid, dorsally convex, with slightly rounded tip, in J1 with very slightly distinguished $3 \mu \mathrm{m}$ long mucro.

Males: not found.

Intersex: similar to female, $4.3 \mathrm{~mm}$ long, ventrally more coiled in the posterior part. Lip region $11.6 \mu \mathrm{m}$ wide and 5 $\mu \mathrm{m}$ high. Oesophageal bulb measuring 89 × $20 \mu \mathrm{m}$. Vulva well developed, in shape related to female vulva. Anterior genital branch $224 \mu \mathrm{m}$ and posterior branch $264 \mu \mathrm{m}$ long, respectively. Anterior uterine part $92 \mu \mathrm{m}$ long; part with particular characters indistinct. Posterior uterine part without particular characters $88 \mu \mathrm{m}$ long, part with particular characters $43 \mu \mathrm{m}$ long. Spermatheca and ovary of anterior and posterior genital branches indistinct. The male reproductive system reduced, spicules arcuate, well developed, $44 \mu \mathrm{m}$ long. The adanal pair of supplements preceded by a row of 11 ventro-median supplements. Tail dorsally convex, conical, tapering, with slightly subdigitate terminus and almost pointed tip. The morphometrics of the Slovak intersex resemble the Serbian one (Krnjaic et al., 1999); some slight differences are e.g. in „b“ ratio 13.2 vs. 9.8, somewhat longer tail $62.0 v \mathrm{~s} .56 \mu \mathrm{m}$, a larger body diameter at vulva $48.0 v s .41 .1 \mu \mathrm{m}$ and at anus $35.0 v s .28 .9 \mu \mathrm{m}$. In contrary to the Serbian specimen of intersex, the Slovak specimen has well developed spicules.

Females of L. distinctus from Slovakia, in having mostly longer and more slender body and slightly longer odontostyle than females from eastern Serbia (Krnjaic et al., 1999), are more similar to the type population from Bulgaria (Lamberti et al., 1983) and to a population from northern Serbia (Barsi and Lamberti, 2003). Their morphometrics also resemble morphometrics of Longidorus rubi Tomilin \& Romanenko in Romanenko, 1993 (Romanenko, 1998) and concurrently varied e.g. in having longer and thinner body, longer odontostyle, shorter odontophore, shorter tail and different structure of female reproductive system.

L. distinctus was originally described from Bulgaria from the type locality at Kovachitsa with walnut (Juglans regia L.) and quince (Cydonia oblonga Mill.) trees, but the species is distributed throughout the country in the rhizosphere of various fruit trees, grapevine, ornamentals, cereals, potato and other plants (Lamberti et al., 1983; 1997) as well as in forest nurseries (Peneva and Choleva, 1992). Besides Bulgaria, the species was found in the rhizosphere of grapevine (Barsi, 1989; Barsi and Lamberti, 2003) and quince in Serbia, where an intersex was also recorded (Krnjaic et al., 1999), as well as in the rhizosphere of raspberry and apple in the Ukraine (Romanenko, 1998).

\section{Molecular study}

Two female specimens were sequenced directly from purified PCR products. Identical sequences were obtained for both specimens. The obtained sequence was deposited in NCBI (National Center for Biotechnology Information) with accession number EF654539. A BLAST (Basic Local Alignment Search Tool) search at NCBI was performed using $L$. distinctus as queries to search for similar sequences deposited in GenBank. The BLAST results showed no identical sequences. It showed $94 \%$ and $93 \%$ homology to L. juvenilis (accession number AY601579 and DQ364599 respectively). Morphologically L. juvenilis is also close to L. distinctus.

\section{Acknowledgements}

This work was supported by Scientific Grant Agency VEGA No. 2/7191/27. The author is thankful to Dr. Kumari for help with the molecular work and photographs.

\section{References}

Aboul-EID, H.Z., CoOmans, A. (1966): Intersexuality in Longidorus macrosoma. Nematologica, 12: 343 - 344

BARSI, L. (1989): The Longidoridae (Nematoda: Dorylaimida) in Yugoslavia. I. Nematol. medit., 17: 97 - 108

BARSI, L., DE LUCA, F. (2005): Morphological and molecular characterization of Longidorus helveticus (Nematoda: 
Dorylaimida) from Serbia. Nematol. medit., 33: 41 - 49 BARSI, L., LAMBERTI, F. (2003): Morphometrics of adults and juvenile stages of three longidorid nematodes (Nematoda: Dorylaimida) from Vojvodina province, northern Serbia. Nematol. medit., 31: $65-85$

BROWN, D.J.F, BOAG, B. (1988): An examination of methods used to extract virus-vector nematode (Nematoda: Longidoridae and Trichodoridae) from soil samples. Nematol. Medit., 16: 93 - 99

CoHn, E., Mordechai, M. (1968): A case of intersexuality and occurrence of males in Longidorus africanus. Nematologica, 14: 591 - 601

De Ley, P., FÉliX, M.A., Frisse, L.M., NAdler, S.A., SternberG, P.W., ThOMAs, W. K. (1999): Molecular and morphological characterisation of two reproductively isolated species with mirror-image anatomy (Nematoda: Cephalobidae). Nematology, 2: $591-612$

Krnjaic, D., Krnjaic, S., Lamberti, F., Agostinelli, A. (1999): New record of Longidorus distinctus Lambetri et al., 1983 (Nematoda: Longidoridae) from Serbia. Nematol. medit., 27: $57-61$

Kumari, S., Polák, J., ChoutKa, R. (2005): Plantparasitic nematodes of the genus Xiphinema (Nematoda: Longidoridae) in the vineyards of the Czech Republic. Nematology, 7: 81 - 93

Lamberti, F., Choleva, B., Agostinelli, A. (1983): Longidoridae from Bulgaria (Nematoda, Dorylaimida) with description of three new species of Longidorus and two new species of Xiphinema. Nematol. medit., 11: $49-$ 72

Lamberti, F., Ioev, T., Choleva, B., Brown, D.J.F., Agostinelli, A., RADiCCI, V. (1997): Morphometric variation and juvenile stages of some longidorid nematodes from Bulgaria with comments on the number of juvenile stages of Longidorus africanus, L. closelongatus and Xiphinema santos. Nematol. medit., 25: 213 - 237

LAMBerti, F., ZACHEO, T.E., MARTELLI, G.P. (1975): Un caso di intersesso in Xiphinema ingens Luc et Dalmasso (Nematoda: Longidoridae). Nematol. medit., 3: 181 - 183 Peneva, V., Choleva, B. (1992): Nematodes of the family Longidoridae from forest nurseries in Bulgaria. I. The genus Longidorus Micoletzky, 1922. Helminthology, 32: $35-45$

RASCHKÉ, I.E., BOAG, B. (1981): Morphological variation and distribution frequency of hermaphrodite Longidorus elongatus. Rev. Nématol., 4: 283 - 285

ROMANENKO, N.D. (1998): Redescription of Longidorus rubi Tomilin \& Romanenko in Romanenko, 1993 (Nematoda Longidoridae) associated with raspberry in the Poltava region, Ukraine. Russ. J. Nematol., 6: 185 - 187

Stanton, J.M., McNicol, C.D., STEele, V. (1998): Nonmanual lysis of second-stage Meloidogyne juveniles for identification of pure and mixed samples based on the polymerase chain reaction. Austral. Pl. Path., 27: $112-$ 115

ACCEPTED JULY 24, 2007 